Dead adult leatherback turtle tangled in a squid driftnet in the North Pacific.

\title{
Driftnets Catch Leatherback Turtles
}

\section{George H. Balazs}

In 1979 Japanese fishing vessels began using monofilament mesh driftnets to catch squid in international waters north-west of the Hawaiian Islands, between $35^{\circ}$ and $45^{\circ} \mathrm{N}$. This new fishery threatens the survival of leatherback turtles Dermochelys coriacea in their North Pacific feeding grounds and migration routes. It is only recently that the existence of leatherbacks in this remote oceanic area has been discovered and made known. ${ }^{2}$

The nets used in the squid fishery are up to $16 \mathrm{~km}$ long and $6 \mathrm{~m}$ deep. Each boat sets out its net to drift at the surface overnight and hauls it back in the morning. The mesh size of these nearly invisible underwater webs averages $12 \mathrm{~cm}$ so that many other species besides squid become entangled. Fishing boats from the United States that troll for albacore tuna in the same region have observed some of the destructive effects. In the summer of 1980 , one albacore boat saw no fewer than 30 and possibly as many as 50 vessels laying nets for squid. In addition to Japanese fishers, some are believed to have been from Taiwan and Korea. The same boat reported seeing at least five dead leatherbacks wrapped in sections of net, floating at the surface. Animals that are too large or difficult to be landed on deck are simply cut adrift with the net still around them. Porpoise, ocean sunfish, sharks, swordfish, and small albacore have all been seen entangled in the squid nets. Several of the US albacore boats themselves also became snarled in the nets when they unknowingly ran into them.

It has been known for some time that large numbers of seabirds and marine mammals are caught and die in salmon driftnets used by Japanese fishermen in the Bering Sea and above $45^{\circ}$ latitude in the North Pacific. This fishery has been in operation since 1952, but leatherbacks are not believed to be affected because the fishing area is mostly outside the northern limits of the turtle's range. However, the annual estimated mortality of seabirds entangled in salmon nets ranges from 280,000 to 760,000 individuals of some 18 species. More than 9000 Dall porpoise Phocoenoides dalli are also believed to be taken each year, as well as smaller numbers of northern fur seals Callorhinus ursinus and several other marine mammals..$^{5,9}$ Lost sections of salmon net are an additional hazard because they continue to entangle and kill wildlife, ${ }^{6}$ and also drift into coastal 
waters with large breeding colonies of various species. Sometimes these pieces travel considerable distances; one was found washed ashore at French Frigate Shoals $\left(24^{\circ} \mathrm{N}\right)$ in the Hawaiian Islands National Wildlife Refuge.

The nets used in the squid and salmon fisheries are similar or even identical; some salmon net vessels are known to have changed to squid fishing. In late 1981 more than 500 Japanese boats alone were reported to be using driftnets for squid in the North Pacific. ${ }^{4}$ Interestingly enough, there are conflicts over the use of these nets within the Japanese squid fishery itself. Fishermen using the traditional, but less efficient, method of jigging for squid with hooks and underwater lights have criticized the net fishery because of its disregard for resource conservation. As a result, Japan has banned the use of squid driftnets in its own waters, and requires $\mathrm{Japanese}$ vessels to stay east of longitude $170^{\circ} \mathrm{E}$ when fishing north of latitude $20^{\circ} \mathrm{N} .4^{4}$

The use of driftnets for squid is attracting attention now in other parts of the world; some exploratory fishing has started in New Zealand, and also in the Tasman Sea ${ }^{1,3}$ where the technique has proved effective. However, it is not known whether there is any incidental capture of sea turtles or other non-target species. The use of driftnets for commercial shark fishing on the high seas has been tried in the North Pacific and is likely to be extended. ${ }^{7}$ Taiwanese boats have been setting driftnets for sharks and fish off northern Australia since 1974, but again nothing is known about the incidental catch. ${ }^{8}$

Due to their great size and catching ability, driftnets clearly pose a substantial threat to sea turtles that reside in or migrate through the fishing area. The leatherback is the most pelagic of the seven sea turtle species, and has generally been considered secure once away from the nesting beaches. With the expanded use of driftnets on the high seas this may no longer be the case. Because the early life-stages of all sea turtles involve some pelagic existence, the other six species are also liable to be affected.

The use of driftnets and their incidental take of sea turtles and other wildlife need to be carefully monitored. At the same time, both private and government agencies concerned with conservation should be made aware of this growing fishery so that appropriate actions can be taken.

\section{Acknowledgments}

Appreciation is expressed to Jerry Ray, Anthony Degange, Skip Naftel, Linda Jones and Craig Harrison for providing information and articles instrumental in the preparation of this note. Contribution No. 629 of The Hawaii Institute of Marine Biology.

\section{References}

1. ANONYMOUS. 1980. Nine Squid Projects off South-East. Australian Fisheries 39, $1: 3$.

2. BALAZS, G.H. in press. Status of Sea Turtles in the Central Pacific Ocean. The Biology and Conservation of Sea Turtles, Smithsonian Press. Paper presented at the World Conference on Sea Turtle Conservation, November 1979, Washington, DC.

3. COLLINS, S. and M. DUNNING. 1981. Tasman Squid Studies Demonstrate Gillnetting Effective. Australian Fisheries 40, 8: 2-6.

4. COURT, W.G. 1981. Recent Trends in the Japanese Fishery for Squid, Ommastrephes bartrami. Administrative Report H-81-8, Southwest Fisheries Center, Honolulu Laboratory, National Marine Fisheries Service, 7 pp. 
5. DEGANGE, A.R. 1978. Observations on the Mortality of Seabirds in Japanese Salmon Gillnets made from the Oshoro Maru and Hokusei Maru, Summer, 1978. Pacific Seabird Group Bulletin 5, 2: 1-38.

6. DEGANGE, A.R. and T.C. NEWBY. 1980. Mortality of Seabirds and Fish in a Lost Salmon Drift net. Marine Pollution Bulletin 11: 322-3.

7. MAKIHARA, M. 1980. Toward Effective Utilization of the Abundant Shark Resource. Suisan Shuho (The Fishing and Food Industry Weekly), 898: 22-6. Translation No. 52 by T. Otsu, Southwest Fisheries Center, Honolulu Laboratory, National Marine Fisheries Service, $8 \mathrm{pp}$.

8. MILLINGTON, P. and D. WALTER. 1981. Prospects for Australian Fishermen in Northern Gillnet Fishery. Australian Fisheries 40, 9: 3-8.

9. NATIONAL MARINE FISHERIES SERVICE. 1981. Final Environmental Impact Statement on the Incidental Take of Dall Porpoise in the Japanese Salmon Fishery. United States Department of Commerce, Washington, DC. 99 pp.

George Balazs, Hawaii Institute of Marine Biology, PO Box 1346, Kaneohe, Hawaii 96744.

\section{Earlier Sightings of Humpback Whales in Antarctica}

Nigel Bonner has documented sightings of humpbacks Megaptera novaeangliae off the west coast of the Antarctic Peninsula which seem to indicate some recovery of stocks (Oryx 16, 3: 231232). It may therefore be worth placing on record the following sightings of this species made from Argentine Islands for $1970 / 72$, when I was stationed at the British Antarctic Survey base.

Daily watches were kept for whales in the course of maintaining bird records. The 12 records of cetaceans in 1970 and 23 in 1971 were all confined to the period January-June, and all but four to March-May. None of the 1970 records were thought to involve humpbacks, but in 1971 there were four positive sightings in the period 21-30 April. On 21 April, of five whales seen in Penola Strait at least two were humpback. They breached on several occasions, waving their long black and white fins in the course of playful behaviour. The following day I spent about an hour watching three humpbacks only a few hundred yards off the island group. On 23 April, ten whales were seen but were lost in fog before positive identification could be made. None were seen on 24 April but the following day two humpbacks were present with a group of four small rorquals. The humpbacks remained motionless on the calm surface side by side, so that through a telescope the knobs in front of the blowhole were easily visible. My final sighting was on 30 April, when again two individuals spent a considerable time resting side by side at the surface. These four records could have involved only three individual humpbacks, or, if there was a steady southward movement, at least. nine. Late summer movements of whales into this area of the Antarctic Peninsula waters appears to be a regular phenomenon.

Peter Kinnear, 11 Hill View Road, Balmullo, St Andrews, Fife KY16 0DE.

\section{Protection for Olive Ridleys}

President Carazo of Costa Rica has declared the beach of Ostional, Guanacaste, a protected breeding area for olive ridley turtles Lepidochelys olivacea. Along with the neighbouring, already protected Nancite beach, Ostional was considered second in importance of 38 nesting areas by the World Conference on Sea Turtle Conservation in 1979. 